\title{
8 The Afterlife of a Multinational Enterprise
}

\section{The Case of Siemens' Subsidiary in Hungary After the Second World War}

\section{Judit Klement}

\section{Introduction $^{1}$}

In the history of Siemens as a multinational enterprise, on several occasions the company was faced with non-market forces or effects. According to W. Feldenkirchen (the 'official' historian of Siemens), for example, the attempt to establish a workshop in Paris in 1878 was a failure because of 'the intensity of anti-German sentiment' after the Franco-Prussian War. ${ }^{2}$ Similarly, during the First World War, Britain confiscated the Siemens plants in England, ${ }^{3}$ and the new boundaries of the successor states in Central Europe (including Hungary) after the war also compelled the Siemens subsidiaries to adapt to dramatic changes. However, the biggest non-market challenge came after the Second World War. In Germany, the main question was Siemens's participation in the Nazi economy, 'from producing armament to employing concentration camp labour'. ${ }^{4}$ The company and its leaders had to cope not only with prosecution for war crimes but also with an appalling reputation. ${ }^{5}$ The future of Siemens's assets beyond the German borders, furthermore, was in the hand of the Allies. After the Potsdam Agreement, German wealth was regarded by the Allies, especially the Soviets, as a source for reparations. The Hungarian government signed the armistice in Moscow on 20 January 1945, and the country was occupied by the Soviet army. The Siemens subsidiary in Hungary was a wholly owned German subsidiary, and so it was considered a source for reparations to the Soviets. On the basis of these developments, the history of Hungary's Siemens's subsidiary should have been quite straightforward after 1945, but the reality that emerged was more complex. Both the (ex-)Siemens employees and the Hungarian state tried to change the scenario originally sketched out in Moscow and in Potsdam. These attempts and the events in 1945 and 1946 are the focus of this chapter, in which the fate of Siemens in Hungary after the war will be analysed. 


\section{Judit Klement}

\section{Siemens in Hungary Before 1945}

Siemens, established in 1847 and at the time headquartered in Berlin, first appeared on the Hungarian market as a joint venture in 1887 . The company played a major role in the construction of the newly formed tramway system of Budapest. ${ }^{6}$ In 1894, Siemens set up its own Hungarian subsidiary, initially in a form of a limited partnership and then (from 1900) as a joint-stock company. ${ }^{7}$ It is well known that Siemens had been functioning as a multinational company since the 1850 s. It had both more and less successful subsidiaries. ${ }^{8}$ The subsidiary in Budapest was among Siemens's small but efficient foreign direct investments. The operation of Siemens in Hungary began with the construction and upkeep of Budapest's tramway system. In 1896, Siemens also took part in the construction in Budapest of continental Europe's first underground railway. These functions were at the core of the construction and maintenance of electric plants and, later, the electrification activity of the Hungarian Siemens subsidiary. For over a decade, the Siemens' workshops in Budapest functioned as repair and operating facilities rather than a production plant. ${ }^{9}$

Siemens did not begin production in Hungary until 1904. In that year, the German Siemens and Schuckert firms merged, and so Siemens became a co-owner in Hungarian Schuckert Works and, thereby, a factory owner, because the Schuckert Works already included a machine factory in Pozsony (Pressburg, today Bratislava, Slovakia). The majority of the newly formed Hungarian Siemens enterprise-the precise name of which was Hungarian Siemens-Schuckert Works Electrical Engineering Joint-Stock Company (Magyar Siemens-Schuckert Müvek Villamossági Részvénytársaság)_belonged to the Austrian Siemens subsidiary (Österreichische Siemens-Schuckert Werke AG.-Austrian Siemens-Schuckert Works), and not directly to Berlin (Siemens \& Halske AG.). ${ }^{10}$ In addition to the machine factory, the company also planned to build a cable factory. The new plant was constructed in Kóbánya, a neighbourhood on the outskirts of Budapest. The purchase of the plot in Kóbánya and the construction on the site of its factory in 1913 was the first production initiative of Hungarian Siemens-Schuckert Works.

After the First World War, the machine factory in Pozsony was lost for the Hungarian Siemens subsidiary when it was annexed to the Czechoslovak Siemens enterprise. ${ }^{11}$ So, in 1927 , Siemens Hungary started to build a machine workshop in Kóbánya, on which work was completed in 1936. As Siemens's profile expanded worldwide, production in Budapest became more diversified. In the 1930s, the machine factory of Hungarian Siemens-Schuckert Works also began to produce household appliances, in addition to dynamos, switches, engines, etc. Until 1934, another Hungarian Siemens subsidiary handled electrical engineering (low-voltage products), at another plant. ${ }^{12}$ But in 1934 this section was merged with Hungarian Siemens-Schuckert, and in 1937 it was moved to Kóbánya.
The main profile of the latter was radio production and the manufacture The main profile of the latter was radio production and the manto factories were working at Siemens's plant in Kóbánya: a cable factory, machine and an electrical (low voltage) engineering factory.

As a consequence of preparations for war in Hungary-the so-called Gyôr Project-and the orders placed by the state during the Second World War the Hungarian Siemens subsidiary expanded rapidly. ${ }^{13}$ The plant was War, the and a half times its size in extended, and by 1942 it had ince 1913. The number of employees also grew continuously; the three factories together employed more than 1,500 people in $1942 .{ }^{14}$ Development was followed by a capital increase. In 1941, the company raised its capital was followed 4 to 6 million pengôs. By this time, 'Schuckert' had disappeared from the official name of the Hungarian firm in alignment with the name of the German parent company. ${ }^{15}$ In the 1940 s, the Hungarian Siemens of the German parent company. ${ }^{15}$ In the 1940s, the Hungarian Siemens subsidiary was called Hungarian Siemens Works Electrical Engineering Joint-Stock Company (Magyar Siemens Müvek Villamossági Részvénytársaság), and it functioned under full German ownership in Budapest.

During the Second World War, the cable factory and the machine fac-

During the not seriously damaged, but the low-voltage engineering factory tory were not seriously damaged, but the low-voltage engineering factory was bombed and destroyed at the beginning of 1945 . With the excep tion of the days of the siege of Budapest, the Siemens plant in Kóbánya continued production until the remaining factory parts were dismantled in March 1945.

\section{Booty and Reparation}

As an ally of Nazi Germany, Hungary was defeated in the Second World War, and the Soviet Union occupied the entire country in 1945. The war inflicted immeasurable human casualties and tremendous material losses. According to the secondary literature, the number of people who died as a consequence of the war in Hungary (delineated by the 1941-1944 borders) was $340,000-360,000$ military casualties and 410,000-460,000 victims of the $340,000-360,000$ mith Holocaust. ${ }^{16}$ This puts Hungary in third or fourth place in the ranking of human casualties of the war if the number of casualties is given as a percentage of the country's population. The country was also materially ruined. Budapest suffered in particular at the end of the war. The siege of the capital, which lasted for more than 100 days, was similar to the bloody blockade of Stalingrad, Warsaw and Berlin in terms of loss of life. ${ }^{17} \mathrm{~A}$ few facts serve to give a good impression of the state of affairs in the country after the war. ${ }^{18}$ For instance, 40 percent of the national wealth of 1938 was destroyed during the war. Livestock suffered an especially serious loss, as 56 percent of the stock of 1944 perished, which caused immediate difficulties in the post-war food supply and in the resumption of agricultural production. The country struggled with severe problems 


\section{Judit Klement}

concerning provisions for the citizenry, partly because the transport system had been incapacitated. The country's obligation to supply provisions for the occupying Soviet army and its allied Romanian, Bulgarian and Yugoslav forces made the situation more difficult, and the situation was made even more intense by the immediate start of Soviet war reparations.

By signing the armistice (20 January), the Hungarian government ${ }^{19}$ accepted the Soviet Union's claim for compensation for war damages (a claim which was also made by Yugoslavia and Czechoslovakia). One month later (20 February), Hungary received a detailed catalogue, composed in Moscow, of the goods and products which were to be delivered to the Soviet Union over the course of the next six years. The Hungarian government could not acknowledge this catalogue-as was promptly noted in an official answer. They were unable to assess the situation: the government was only able to move its seat to the capital on 19 April when the front line of the war was no longer in the country. Moreover, most of the industrial plants and mines remained under Soviet military control until summer 1945, which meant that they were in use primarily to meet military needs ${ }^{20}$ and were closed to civilians and even government representatives. From April to mid-June, long and exhausting negotiations took place concerning reparations to be paid by Hungary. This process came to an end with the so-called reparation agreement on 15 June. However, the removal of Hungarian valuables, engines, machinery and other assets had begun much earlier, in the spring of 1945, without any mutual consensus, and it continued until summer, independently of the reparation agreement. The Hungarian government, more precisely the Foreign Office, protested several times against what in its eyes was simply plunder, but unsuccessfully. The arbitrary dismantling gradually ceased after the signing of the reparation agreement, but the value of the goods which had been appropriated was not taken into account in Hungary's obligation to make reparations. ${ }^{21}$

The dismantling and removal of the factories of Hungarian Siemens Works Electrical Engineering Joint-Stock Company started on 15 March 1945. By the time it had come to an end, there were only empty buildings left in the cable and machine factory complex. ${ }^{22}$ (The low-voltage engineering factory had been destroyed during the siege of the capital.) In one of the many official protests of the Hungarian Foreign Office (dated $25 \mathrm{May}$ ), the company was named among the firms which were not mentioned in the reparation list but which had still been totally dismantled. ${ }^{23}$ (Before this protest, on 14 May, the Hungarian government received a final list containing the exact names of factories which had to be fully dismantled and removed as part of the reparations to the Soviet Union.) The loss of Hungarian Siemens Works was especially dramatic for the country, because together with the dismantled cable factory of Felten $\&$ Guilleaume, it meant the complete disappearance of the Hungarian cable manufacturing industry in spring $1945 .{ }^{24}$
Legally, no change occurred in the management or ownership system of Hungarian Siemens Works in 1945. The directorate which had been elected at the last general assembly in 1944 remained in charge, with two German members among the directors: Ernst Siemens and Dr. Hermann German members among the directors: Ernst Siemens and Dr. Hermann on 21 June 1944, though Wilchelm Mader, a representative of the Berlin firm, did. In these turbulent months, the company was led by the Hungarian directors, with the managing director and director of trade, Miklós Kemper, and the other managing director and technical director, Aladár Szentmártony, playing particularly prominent roles. In summer 1945, as one of the stipulations of the Potsdam Agreement, German properties beyond the borders of Germany were declared objects to be used as reparations for war damage by the Soviet Union. Hungarian Siemens Works operated under full German ownership, so it was only a question of time before the change of ownership would occur.

The legal uncertainty surrounding the Hungarian Siemens subsidiary became obvious at the beginning of 1946. A letter written on 30 January 1946 by Zoltán Tildy, the Hungarian prime minister and president of the Chief Economic Council of Hungary, ${ }^{25}$ announced to the leaders of Hungarian Siemens Works that all of the company's shares, which were valued at a total of 6 million pengös, were being given to the Soviet Union as reparations, in accordance with the decisions reached at the Potsdam conference and because the company was in German ownership. Quoting the letter, the government of the Soviet Union would be authorised to exercise the 'shareholders' right'. ${ }^{26}$ This meant en passant that the form of the business would remain a joint-stock company and the Siemens name would be retained. Consequently, there were general assemblies and the directorate and the board of supervisors elected at the assemblies would continue to work formally according to the constitution. But the members of the management changed as one of the conditions.

The new management of Hungarian Siemens Works was elected only at the extraordinary assembly on 19 October 1946, months after the January decision of the Hungarian state. The assembly removed all members of the leadership who had held positions at the company in or before 1944, and they changed the constitution of the company. The assembly deleted the paragraph from the constitution, which secured a majority for the Hungarian members on the directorate, and it also deleted a paragraph according to which women were not allowed to vote at the assembly. The newly elected board of directors consisted of seven Soviet members and one Hungarian, and the board of supervisors had four members, three Soviet and one Hungarian, and two of the three Soviet members were women. The Soviet participants in the leadership worked as officers at the Soviet Property Holding Office of Hungary. ${ }^{27}$ Alongside the Soviet managing director (Ivan Odajnik, who was followed by another Soviet officer, Nyikolaj Romanov, in September 1947), the second most important 
executive was a Hungarian citizen (Andor Pollák, in some documents Adolf). He was the only Hungarian member of the directorate, and he had not held any position at Hungarian Siemens Works before.

Little is known about the Soviet era of Hungarian Siemens Works Electrical Engineering Joint-Stock Company, apart from the fact that it was under Soviet ownership and control. However, there is evidence to suggest some glitches in its operations. For instance, in a letter written on 15 April 1947, the previous managing director, Miklós Kemper, complained that he had not received any official dismissal notice regarding his employee status. According to the letter, Odajnik had informed him orally, after the general assembly in October 1946, when Kemper was removed from the directorate, that he, Odajnik, would be the managing director from then on. Moreover, Kemper stated that the company continued to use his services. ${ }^{28}$ This practice of retaining a looted company and of doing so as if this were a normal manner of operation can be understood only by studying the nature of the firm in the years which followed.

\section{An 'Alternative' Siemens Company}

After the factories of Hungarian Siemens Works had been dismantled and removed in the spring of 1945, the leadership of the firm-the original Hungarian-dominated management, decided to give many Siemens employees notice to quit, probably because of the uncertain future of the German-owned company. We do not know how many employees were affected, but 27 people, presumably most of them among the affected, decided to establish a new entity with the name Joint-Stock Company for Electrical Engineering Industry and Trade, or Vikert, the abbreviated form of the Hungarian name (Villamosipari és Kereskedelmi Részvénytársaság). ${ }^{29}$ The proposed foundation rules were formulated on 22 May 1945 and signed by 27 (ex-)Siemens officers and chief engineers. On the list of the 27 founders, one finds among the chief engineers and officers Miklós Kemper and Aladár Szentmártony, the two managing directors of the still-existing Hungarian Siemens Works. They each continued to hold positions at Hungarian Siemens Works when they signed the foundation document, so they cannot be seen as ex-Siemens personnel. This fact indicates that Hungarian Siemens Works and Vikert existed in parallel, and it also gives an impression of the significance of the founders group. One could consider the founders a reservoir of crucial knowledge about Siemens's production processes and management in Hungary. Three weeks later, on 12 June 1945, the first assembly (the statutory meeting) of Vikert was held in the Hungarian Siemens headquarter (Budapest, Teréz Boulevard 36); by then, 171 shareholders had invested capital in the firm in the amount of 400,000 pengôs ( 2,000 shares at 200 pengôs a share).

The foundation rules and the articles of association of Vikert did not mention Siemens in any way, but the aims and profiles of the new firm were identical word for word with the ones in the last articles of the association of Hungarian Siemens Works from 1943. The seat and the plant of Vikert-registered by the Registry Court Budapest on 3 July-were also the same as those of Hungarian Siemens. Furthermore, Vikert rented the Siemens plant in Kóbánya from Hungarian Siemens Works. ${ }^{30}$ Undoubtedly, these 171 persons planned to restart production at the Siemens plant in Kóbánya as their own enterprise, using their newly collected capital.

The modest registered capital of the company (amounted to 400,000 pengös) was provided mostly by minority shareholders. Most of the subscriptions for shares were valid for fewer than ten shares, at a value of less than 2,000 pengôs (this was true in the case of 122 shareholders). There were only six shareholders who subscribed for 50 or more shares, at a value of 10,000 pengôs. (Electrical engineer László Mayerhuber invested 10,000 pengős; engineer officer István Falusy invested 18,000 pengős; radio engineer Dezső Gregács invested 20,000 pengős; commercial officer József Tóth invested 25,000 pengős; chief engineer Béla Mittelholzer invested 25,000 pengős; and commercial officer Salamon Lichter invested 100,000 pengôs.) These six individuals were the biggest shareholders in the new company. The director of trade and still managing director of Hungarian Siemens Works, Miklós Kemper, purchased five shares at a value of 1,000 pengôs, and Aladár Szentmártony, the other managing director of Hungarian Siemens Works, bought 25 shares for 5000 pengôs. ${ }^{31}$

The directorate of the new company, which was elected by the first assembly, had five members, each of whom had been one of the 27 founders. Four out of the five were also 'big' shareholders (László Mayerhuber, Béla Mittelholzer, József Tóth, and Salamon Lichter). ${ }^{32}$ The directorate elected a president from among its members, József Tóth, who also served as managing director. Before holding these positions in Vikert, József Tóth had been working at Hungarian Siemens Works for 21 years. ${ }^{33}$

In the early summer of 1945 , inflation was still moderate. The 400,000 pengős capital had some value, but it was nowhere near enough for the resumption of an electrotechnical profile. For the sake of comparison, the last listed capital of Hungarian Siemens Works amounted to 6 million pengós. Securing investment or credit in Hungary or from an international loan in the immediate aftermath of the war was hardly seen as a simple task. The financial sector started to operate again in the spring of 1945 , but the banks did not have significant capital for allocation; the only substantial source of money was the central bank (the so-called National Bank). No relevant governmental economic policy was adopted until the summer. Instead, there were only ad hoc provisions. But from mid-1945, when the official delivery of reparations started, one of the main goals became to start and secure industrial production, and for that purpose the state was ready to give loans. ${ }^{34}$ The foundation of Vikert closely followed developments at the time. In all likelihood, the new company leadership 
entered into negotiations to get capital immediately after it had been founded and perhaps even before. Whatever the case, in the summer of 1945, it was given a credit of 2 million pengôs from the Ministry of Industry. Together with the credit for starting production, a ministerial commissioner-Károly Thamó-was delegated to the company, and he attended the board meetings. ${ }^{35}$

Over time, the presence of the government grew stronger in this enterprise, which initially had been a kind of bottom-up venture. The source of the idea is not yet known, but the concept appeared already as a fact at a board meeting in September 1945, when the Ministry of Industry expressed its willingness to purchase the shares of Vikert at a value of $3,600,000$ pengös, which included the earlier loan of 2 million pengôs. Thereby, the listed capital of the company would have increased to 4 million pengôs and the Hungarian state would have become the major shareholder, owning 90 percent of the enterprise. For having made such an investment, the Ministry of Industry would delegate nine members to the directorate. The plan required that the company raise the capital by issuing 18,000 shares, on which a decision was made at the extraordinary assembly on 20 September 1945 . The minutes noted that the new shares would be offered to the Hungarian Treasury. The Ministry of Industry paid the value of all new shares into the company's current account at Pest Hungarian Commercial Bank on 13 October 1945, so the plan became a reality. It is not possible to detect any significant reduction in the number of old shareholders comparing the share owners and deposits in June, September, or November 1945, so for the most part they clearly held on to their property and continued to believe in Vikert after the state obtained the majority of shares. ${ }^{36}$

The directorate resigned on 16 October 1945 . The new board of directors was elected by the extraordinary assembly on 19 November 1945 , and it was expanded to 12 members. Out of the 12 members, five came directly from the Ministry of Industry (one undersecretary, one head of department, and three ministerial councillors), and the Ministry of Finance delegated one of its ministerial councillors. The Central Corporation of Banking Companies was represented by a vice-director (Károly Thamó, who had already been delegated to the company as ministerial commissioner of the Ministry of Industry in the summer of 1945), and the Trade Union Council also delegated a member to the board. These eight members were newly elected, and they served as representatives of the state. The ministry nominated an additional member, a worker from Vikert (Ferenc Egyedi), who was intended to represent the workers of Vikert on the directorate. (Ferenc Egyedi had not been one of the founders of the company and had not had any shares before.) Only two members of the original directorate, László Mayerhuber and József Tóth, remained. The explanation for why László Mayerhuber remained on the directorate is interesting. He had been one of the founders of Vikert in May. He had purchased shares (50) in June, but he had also worked as chief engineer at IKART, a company which was in charge of coordinating reparation transfer under the control of Ministry of Industry. Thus, Mayerhuber could also be considered a representative of the Ministry of Industry. His presence clearly indicates the importance of Vikert in Hungary's process of making reparations to the Soviet Union, which offers a plausible explanation for the interest and investment of the Ministry of Industry in the company.

The assembly on 19 November 1945 elected one more member to the directorate, Aladár Szentmártony, who had served as managing director at Hungarian Siemens Works since 1937 and who had purchased 25 shares of Vikert at the time of its foundation. József Tóth remained in his position as managing director and director of trade, but Károly Thamó, the ministerial commissioner and new 'company leader', had more power. According to the original concept of the Ministry of Industry, Tóth should have been in charge of administrative management and Szentmártony of technical management, both of which were under the leadership of Thamó. (Earlier, in the administration of Hungarian Siemens Works, two managing directors had always worked side by side, one as the administrative leader and the other as technical leader. Obviously, Vikert tried to revert to this old, Siemens-type form of management.) However, Szentmártony worked as a technical advisor at Vikert. He refused to accept responsibility as a technical managing director. ${ }^{37} \mathrm{He}$ may have done this in part because, at the end of 1945, the Hungarian Siemens subsidiary still existed legally in its pre-war structure, so Szentmártony worked there as technical managing director and member of the directorate. This caution on his part is again a sign of parallelism, i.e. for a time the two companies existed side by side.

The membership of the board of supervisors ${ }^{38}$ at Vikert was similar to the directorate. The Hungarian Treasury nominated two officers from the Ministry of Industry to this board and one from the Ministry of Finance, as well as a repairman at Vikert. For the fifth position, the assembly could elect a member, and they chose Miklós Kemper, the director of trade and managing director, to work alongside Szentmártony, who had been the second man at Hungarian Siemens Works since 1937.

The resumption of production by Vikert in 1946 brought an array of challenges for the management. Shortage of raw materials was a continuous problem; equipping and making the necessary repairs to the empty factory buildings also posed a serious challenge; the management also needed to handle the problem of low voltage (electrical) engineering and needed to handle the problem of low voltage (electrical) engineering and the war. It was also difficult to evaluate what the company was worth, make an inventory, and assess the value of the raw and semi-raw materials. The assessment was made more difficult by the fact that some of the semi-raw materials had lost their value-temporarily-on account of 


\section{Judit Klement}

the shortage of raw materials. Finally, the management had to deal with continuous financing problems.

Moreover, after the summer of 1945, inflation broke loose, which complicated financing and the work of assessment. The value of the pengő started to plummet at the beginning of 1946, which prompted the government to issue currency denominated in almost incomprehensible amounts, for instance one million-million pengôs or hundred-millionbillion pengôs. The Hungarian currency lost its value in practice, and people tried to get ahead without using it. They found other means of payment, like gold, foreign currencies, and any kind of foodstuff or other goods. Even companies adopted the practice of barter rather than the use of currency. The minutes of a Vikert's board meeting mentioned that the firm received tins-for example, rabbit pâté-in exchange for three engines. ${ }^{39}$ The hyperinflation of 1945 and 1946 (the worst ever in the country's history) forced the government to replace the pengô with a new currency. The forint was introduced on 1 August 1946.

Despite all the difficulties it faced, Vikert succeeded in restarting the production. Naturally, the main task of the company was to produce goods which the country used to pay its reparations. The manufacturing in the machine and cable factories began as early as 1946, and the new building for the low-voltage engineering factory was under construction at the (Siemens) plant. Meanwhile, Vikert had rented a nearby plot in Köbánya, where the company had started the production of radios in September 1945. So, Vikert worked, the directorate held regular meetings, and together with the leading operatives, they tried to handle all the problems that arose. According to a memo written by József Tóth, ${ }^{40}$ the administration of Vikert was built on the foundation of the hierarchy that had been established in Hungarian Siemens Works, and the system did not change when the state became the major shareholder.

Vikert can be deservedly seen as an 'alternative' Siemens company. The founders (mainly) belonged to the Hungarian Siemens subsidiary, and most of the original shareholders (June 1945) had also been Siemens employees beforehand. The production profile and the management structure were again clearly part of the heritage of the Siemens past. Moreover, the headquarter of Vikert-as announced to the Registry Court-functioned at the same registered address (Budapest, Teréz Boulevard 36) as Hungarian Siemens Works. And finally, the production for Vikert took place at the plant in Kóbánya that Hungarian Siemens Works had used for production before 1945, simply because Vikert rented the plant from Hungarian Siemens Works. The staff of Vikert restarted production successfully, and the Hungarian government was ready to provide support (loans and investments) for the company, because they needed factories that were as productive as possible as quickly as possible in order to help the country meet its reparations' obligations. At the beginning of 1946, when Hungarian Siemens Works became the property of the Soviet
Union, the Hungarian Siemens subsidiary ceased to be under German ownership, but Siemens's business culture lived on at Vikert.

\section{The End of the Story in an East European Version}

At the end of 1946, Vikert was also transferred to Soviet ownership. According to a letter of the Hungarian Reparations Office written on 24 December $1946,{ }^{41}$ the shares of Vikert needed to pass into Soviet proprietorship because of the Hungary's reparations obligation. However, Vikert had been established as an independent enterprise in the summer of 1945 , and 90 percent of the shares of Vikert belonged to the Hungarian state and 10 percent to Hungarian private shareholders. Nonetheless, in the end, the company was transferred to Soviet ownership because of Germany's reparations obligations. This means that Vikert was declared a successor to Hungarian Siemens Works.

As noted above, Vikert rented the site from Hungarian Siemens Works and started production successfully. The foundation of this success was the knowledge which was brought to the company by the former Siemens employees. At the beginning of 1946, when Hungarian Siemens Works was transferred entirely to Soviet ownership, the Soviet Property Holding Office of Hungary informed Vikert that it would not accept the earlier rental contract, and it was also not willing to sell the property where Vikert operated. Vikert had to assess the possibility of vacating the site or merging into the Siemens Works. The Soviet Office also initiated an investigation to determine whether or not Viker had obtained any Siemens valuables. Although the investigation concluded without finding any proof, the Soviet (Siemens) ownership made the negotiations complex. Formally, the matter was a business disagreement, but the Hungarian Ministry of Industry, as the major shareholder of Vikert, had to take into consideration Soviet interests. During the negotiations, both companies (Soviet Siemens and Vikert) were valued, and according to the assessments, Vikert had a value of 7 million forints, while the Siemens Works was worth only about 1.5 million forints. In spite this, in the end, the Ministry of Industry turned all its Vikert shares over to Soviet ownership. The minority Vikert shareholders got some compensation. ${ }^{42}$

The case of Vikert and Hungarian (Soviet) Siemens Works should be interpreted in a broader context. What happened to Vikert in 1946 was of course influenced by the fact that the Soviet army was present as an occupying power, and the Soviets exerted a profound and continuous influence on the Hungarian political situation, primarily simply by strengthening the position of the Hungarian Communist Party. The first election after the war (4 November 1945) resulted in the victory of the Independent Smallholder's Party (57 percent), although a coalition government was formed, according to the Soviet purpose. For the new government, the economic situation, production and the obtaining of funds 
to meet reparations obligations remained crucial tasks. In order to coordinate efforts to address these various tasks (reconstruction, reparations and economic policy) the government established an economic institution with oversight powers- the Chief Economic Council-in December 1945. Although the president of this body was the prime minister (Zoltán Tildy) from the Smallholder's Party, the Secretariat of the Council as an initiative and executive body was led by a Communist-Zoltán Vas. Through the Council and its Secretariat, the Communist Party secured a key role in government control of economic issues. The Ministry of Industry remained essentially in the hands of the Social Democrats after the election, but all the ministries lost their importance as they fell under the shadow of the Chief Economic Council.

In parallel with the Council, the state intervened ever more vigorously in the economy and in business life. The first wave of nationalisations at the end of 1945 affected the coal mines in the country. As a next step, at the end of 1946, the five biggest, heavy industry companies were taken into public ownership, but-at the time-only for the period of reparations. Radical nationalisation began only a year later, at the end of 1947, but in 1946 governmental intervention in the economy was more significant than anything directly affecting the private sector. Because of hyperinflation, the state and the National Bank became the only sources for loans and investments. Moreover, together with the new currency, a new price system was introduced, so Hungarian prices broke away from prices on the international market. ${ }^{43}$

These circumstances were in the background when the Ministry of Industry turned its Vikert shares over to Soviet ownership. Hungarian Siemens Works became Soviet property because of the Potsdam agreement, but the firm had been looted. Real production and value were concentrated in Vikert. But the 'alternative' Siemens company could only be appropriated by the use of the power of the occupying army in a country in which the government and the political system were coming increasingly under Soviet influence.

In 1947, Soviet Vikert was given a new name: Directorate of Soviet Enterprises in the Machine Industry, Joint-Stock Company for Electrical Engineering Industry and Trade Vikert (Gépipari Szovjetvállalatok Igazgatósága, Villamosipari és Kereskedelmi Rt. Vikert). None of the previous members of the leadership remained in their positions. The new management had a Soviet majority and a Soviet managing director. The former managing director (József Tóth) was authorised only to joint procuration. Finally, on 29 December 1947, an extraordinary assembly declared that Vikert would be merged with Hungarian (Soviet) Siemens Works without any exchange value. On 18 March 1948, the Registry Court deleted Vikert from the list of Budapest companies.

Because of the new currency, every company had to create an opening balance in forint. Hungarian (Soviet) Siemens Works-including Vikert, still under its old name (Hungarian Siemens Works), but already in Soviet ownership-issued its forint balance sheet in February 1948. According to the opening balance, the company had a net value of $13,470,000$ forints. The directorate suggested counting 10 million forints as capital and the rest as reserve funds. The proposal was accepted by the assembly and by the chartered accountant, who controlled the balance. So, the listed capital of (Soviet) Hungarian Siemens Works became 10 million forints, with 10,000 shares with a nominal value of 1,000 forints each.

Until 1951, the company worked in Soviet proprietorship as a jointstock company with its original name: Hungarian Siemens Works Electrical Engineering Joint-Stock Company (Magyar Siemens Müvek Villamossági Rt.). The name implied continuity and a Hungarian national identity. Thus, Soviet control was not transparent. In 1951, the name of the firm was changed-Budapest Electrical Company and Cable Factory Co (Budapesti Villamosgép és Kábelgyár Rt.)-Siemens was deleted from its name. In September 1952, the ownership was modified. Hungary and the Soviet Union signed an agreement according to which the Hungarian state could buy back all former German possessions (in Hungary) from the Soviet Union. In the case of former Hungarian Siemens Works, this meant that the Hungarian state paid twice: first, it invested money in Vikert in 1945 and then it had to buy back the company which had been launched in large part thanks to its original investment. So, in the end, the Siemens Works was nationalised but still remained a joint-stock company for some years. Thereafter, the firm operated under the Directorate of Power Equipment in the Ministry of Metallurgy and Mining. The last general assembly of the firm was held in August 1955, where a new leadership was elected by the three representatives of the Ministry. Finally, on 12 May 1960, the Registry Court deleted the company from the list of Budapest firms; the plant and factories in Kóbánya became part of a greater heavy industry conglomerate.

\section{Conclusion}

During the initial period of reconstruction and the resumption of production after the Second World War, the employees of a Siemens subsidiary in Hungary decided to rebuild the enterprise through their own efforts, but as a new company. This new company was named Vikert. The history of the short-lived firm is an important and interesting subchapter in the events of 1945/1946, the significance of which can be summarised in four main points. First, Hungarian Siemens Works still existed legally when Vikert was established as a new enterprise in June 1945. The initiative of the former Siemens employees was motivated by the fact that Hungarian Siemens Works had been dismantled and removed to the Soviet Union in spring 1945, and they had been dismissed. Secondly, four months after the foundation of the firm Vikert, in the autumn of 1945, the Ministry of 


\section{Judit Klement}

Industry invested in the firm and became the majority shareholder. The ministry was primarily concerned with Hungary's reparations obligations. In all likelihood, the ministry saw a potential for production in Vikert, while the German-owned Siemens would hardly be counted against Hungary's reparations, especially given that it was looted and dismantled by the Soviets. Thirdly, with the state owning most of the firm, the leadership was expected to include a representative of the workers as early as October 1945. This is illustrative of a slight change in state economic policy, though it remained a slight change, since the former directors and managers were able to remain in their management positions even though the company was under state control. This was no longer the case under Soviet leadership neither in Hungarian Siemens Works, nor in Vikert. The pre-war managing director of Hungarian Siemens Works, Aladár Szentmártony, for example, was not permitted to remain in the management or even in the company after Hungarian Siemens Works transferred to Soviet ownership, though he was given a new place in the Research Institute for the Electrical Industry. His technical knowledge was valuable in the new regime as well, later he won a state award-the Kossuth prize-for his work. ${ }^{44}$ The staff records of Vikert also prove that for the most part the founding shareholders did not continue to work at Viker after it had come under Soviet control. ${ }^{45}$ The Soviet ownership meant a real dividing line in the history of Siemens and Vikert. Fourthly and finally, as a specific characteristic of this interim and unstable period, in 1946, the Soviet Siemens and Vikert operated side by side, indeed on the same site. Hungarian Siemens Works became Soviet property at the end of January 1946 because of the German reparations duty. Vikert was transferred to Soviet ownership at the end of December 1946 for the same reason. However, this parallelism lasted into 1947. The Soviet Siemens and the Soviet Vikert operated side by side. Only in December 1947 was Vikert merged with the Soviet Siemens, which kept the original Siemens name until 1951, surprisingly. Although Vikert was in operation for only one and a half years-between June 1945 and the beginning of 1947-the management performed well. It managed to restart production, which in and of itself was a huge accomplishment. Indeed, the significance of this achievement can be also seen in the fact that the Soviet Siemens-after the merger with Vikert-had assets of more than 10 million forints at the beginning of 1948, and this assessment was made less than three years after the factories had been dismantled.

\section{Notes}

1 This paper was supported by the János Bolyai Research Scholarship of the Hungarian Academy of Sciences. I would like to thank Aladár Madarász and György Kövér for their comments on my manuscript, and I owe special thanks to Pál Germuska for his useful advice on sources. 2 Feldenkirchen, Werner von Siemens, 91.
3 Wiesen, West German Industry, 41

4 Wiesen, West German Industry, 18.

5 Wiesen, West German Industry, 17-51.

6 Budapest Főváros Levéltára (BFL) [Budapest Municipal Archive] VII.2.e. Cégbírósági iratok (Cg.) [Registry Court Documents] Cg. 34391; Cg. 32673; Budapest közúti vasúti közlekedésének fejlödése.

7 BFL VII.2.e. Cg. 32657; Cg. 2055.

8 Feldenkirchen, Siemens.

9 For the whole history of Siemens in Hungary see Frisnyák and Klement, A Siemens története Magyarországon.

10 BFL VII.2.e. Cg. 2829 (Okm. 1091).

11 The factory in Pozsony/Bratislava became part of the Siemens \& Co. limited partnership in Prague, which merged in 1926 with Elektrizitäts- und Maschinenbau AG. Mohelnice (Müglitz). They were eventually made part of Siechinenbau AG. Mohel mens Elektrizität AG. (in Czechoslovak Elektrotechna). Compass Leonhardt (Vienna, 1929), 1081. On the history of Elektrotechna see Boyer, 'Economic efficiency and nationality', 307-324.

12 The Hungarian Siemens's subsidiaries worked in the same organisational structure as the company did in Berlin and Vienna. The Siemens \& Halske JSC (Budapest)—established in 1900-functioned as the headquarters for the Hungarian market and, later, also as a centre for radio production and reparation. However, the main manufacturing activity-cables and machines-was done by Hungarian Siemens-Schuckert Works. Because of the Great Depression, cuts had to be made to the Budapest subsidiaries, and the Siemens \& Halske JSC (Budapest) was liquidated. Its functions were taken over by Hungarian Siemens-Schuckert Works. (BFL VII.2.e. Cg. 32657); Cg. 2055. Since 1925, the medical device tect company, and this production field remained separate. (BFL VII.2.e. Cg. 7368.).

13 The Hungarian air force ordered e.g. radio and piece parts mainly from the Hungarian Siemens's subsidiary. Kováts, ‘A Magyar Repülőgépszerelvénygyár Rt. története 1941-1950', 160. Trends which were brought about by the war can generally be assessed according to hourly wages in the iron and machine industry. During the war (1941-1944), nominal wages in this sector increased yearly by 21.72 percent on average. Pogány, 'Munkabérek a két világháború yearly by 21.72 percent on aver
közötti Magyarországon', 86 .

14 In 1917 the company had 1,250 employees together in the machine factory (Pozsony) and the cable factory (Budapest). (BFL VII.2.e. Cg. 2829. 58. d. According to some suggestions, during the Great Depression the number of employees decreased significantly. The regeneration began in 1937 when the number of employees rose by 15 percent. The annual reports of the direcnumber of torates mentioned further increases in employment in 1938 and 1939. (BFL VII.2.e. Cg. 2829 (Okm. 1091) 1610 kd.).

15 After the Anschluß, the German-Austrian Siemens-Schuckert property in Vienna became German. Feldenkirchen, Siemens. 1918-1945.

16 Gyarmati, Püski, and Barta, Magyarország a XX. században. I-V. Vol I., 397-398. For details in English see Stark, 'War casualties'.

17 Tamási and Ungváry, Budapest, 1945, 5-20.

18 Honvári, A XX. századi magyar gazdaságtörténet, 85-94.

19 The Temporary National Government-formed according to a four-party coalition-was established in December 1944 and remained in power until November 1945. The prime minister was Colonel General Béla Dálnoki Miklós, who was independent of any political party. Romsics, Magyarország története a XX. században, 277-278.

20 Pető and Szakács, A hazai gazdaság, 51. 
192 Judit Klement

21 Vass G., 'Dokumentumok'.

22 A Villamosgép és Kábelgyár 50 éve, 21, 24

23 Magyar Nemzeti Levéltár Országos Levéltára (MNL OL) XIX-A-58., 116/F. B. irat, A külügyminiszter tiltakozása a Szövetséges Ellenőrzó Bizottságná [Protest of the Minister of Foreign Affairs against the Allied Control Commission]. Quoted in Vass G., 'Dokumentumok' 3.a) document.

24 In Berlin, the situation was similar. 40 percent of the plant had been destroyed. The Soviet troops arrived in Siemensstadt (Siemens City) on 26 April and left it mid-July. They confiscated 22,700 out of a total of 23,100 machine tools (98 percent). Wiesen, West German Industry, 20-21.

25 The election on 4 November 1945 ended in a victory for the Independen Smallholder's Party (57 percent), but because of Soviet pressure (through Kliment Yefremovich Voroshilov), a coalition government was formed. Zoltán Tildy was the president of the winning party and became prim minister. Romsics, Magyarország története, 284-285. The Chief Economic Council was established in December 1945 with the aim of coordinating reconstruction and economic policy. Pető and Szakács, A hazai gazdaság, 65-66.

26 BFL VII.2.e. Cg. 2829 Documents of Hungarian Siemens-Schuckert Works Electrical Engineering Joint-Stock Company, $6033 \mathrm{kd}$. 30 January 1946. Letter of Zoltán Tildy to Marshal Voroshilov (president of the Allied Contro Commission in Hungary).

27 The member of this office represented Soviet interests on directorates of the firms given to the Soviet Union as reparations. One finds the same names on the board of directors of Hungarian Aircraft Assembly Plant JSC as on the board of directors of the Siemens Works, e.g. Georgi Popov, Vladimir Bezugli, and Boris Romanov. (Kováts, 'A Magyar Repülőgépszerelvénygyá Rt. története 1941-1950’, 176.) Hungarian Aircraft Assembly Plant JSC came under Hungarian-Soviet ownership in 1946, because the German share of ownership was only about 50 percent. However this process took less than a year, and the leadership of the firm was controlled by the Soviet members of the directorates.

28 MNL OL Z 11901 1. cs. 1. t. Letter of Miklós Kemper to Hungarian Siemens Works JSC., 15 April, 1947.

29 The narrative of the history of Vikert presented here is based on the following sources: BFL VII 2 e. Cg. 47950; MNL OL Z 1183; Z 1190; A Villamosgép és Kábelgyár 50 éve, 13-45.

30 MNL OL Z 1183 Vikert, Documents of managing directorship, record of 20 November 1945

31 BFL VII.2.e. Cg. 47950, Shares bought and paid in Pest Hungarian Commercial Bank, 5-12 June 1945.

32 The fifth member of directorate was commercial officer Béla Raschovszky, who had 10 shares at a value of 2,000 pengős. BFL VII.2.e. Cg. 47950, statutory meeting on 12 June 1945.

33 MNL Z 1190 Vikert, Department of Staff and Labour, records about József Tóth.

34 Petô and Szakács, A hazai gazdaság, 52, 59.

35 The representation of the state in manufacturing was not unusual, in this instance. In order to ensure continuous production, the Ministry of Industry sent a minis production, 1945. Petô and Szakács, A hazai gazdaság, 52.

$36 \mathrm{My}$ analysis of the shareholders is based on the share subscriptions in June and the share deposits before the general assemblies (12 June 20 September, 19 November 1945). BFL VII.2.e. Cg. 47950.
37 MNL OL Z 1190 Vikert, Department of Staff and Labour, Memo about the job of József Tóth, 7 January 1947, written by Tóth.

38 The Hungarian joint-stock companies operated with a dual board system. The directorate worked as strategic leadership; its members were elected by the shareholders and they reported annually about their work to the shareholders. The directorate appointed the director(s) for operative leadership. The board of supervisors (also elected by the shareholders) controlled the operation of of supervisors (also en the directorate and guaranteed each year that the company worked according to the law and to the interests of the shareholders. The two boards had completely separate memberships.

39 BFL VII.2.e. Cg. 47950, minutes of meeting of directorate on 17 September 1945

40 MNL OL Z 1190 Vikert, Department of Staff and Labour, Memo about the job of József Tóth, 7 January 1947, written by Tóth.

41 BFL VII.2.e. Cg. 47950, a document attached to the extraordinary assembly on 28 April 1947.

42 MNL OL XIX-F-1-b. 44. d. 77.933/V.-1946.IP.M.; MNL OL XIX-F-1-kk. 8.d. The history of the negotiation is presented in Gábor, Jóvátétel és külkereskedelmi orientációváltás Magyarországon, 1945-1949/51, 129-130, accessed 28 December 2017, http://pea.lib.pte.hu/handle/pea/16125

43 Pető and Szakács, A hazai gazdaság, 62-82.

44 'Herr Tuppel csodálkozik'. Népszabadság, 24 October 1958, 2-3.

45 Of the 171 founding shareholders, 99 had an employee registry sheet in the archive. Only 17 of them were still working at Soviet Vikert in 1947. MNL OL Z 1190 Vikert, Department of Staff and Labour, 2. and 3. cs.

\section{Primarily Sources}

Budapest Főváros Levéltára (BFL) [Budapest Municipal Archive]

VII.2.e. Cégbírósági iratok (Cg.) [Registry Court Documents] Cg. 2055 Siemens \& Halske Rt. [Siemens \& Halske JSC].

Cg. 2829 (Okm. 1091) Magyar Siemens-Schuckert Múvek Villamossági Rt. iratai [Documents of Hungarian Siemens-Schuckert Works Electrical Engineering Joint-Stock Company].

Cg. 7368 Magyar Siemens-Reinigen Múvek Rt. iratai [Dokuments of the Siemens-Reinigen Works JSC].

Cg. 32673 Budapest Városi Vasút Vállalat Siemens \& Halske [Budapest City Rail Company Siemens \& Halske]

Cg. 32657 Siemens \& Halske Bt. [Siemens \& Halske LP].

Cg. 34391 Körúti Villamos Vasút Vállalat Siemens \& Halske [Boulevard Tramway Company Siemens \& Halske].

Cg. 47950 Villamosipari és Kereskedelmi Rt. [Joint-Stock Company for Electrical Industry and Trade].

Magyar Nemzeti Levéltár Országos Levéltára (MNL OL) [Hungarian National Archives]

XIX-A-58. Fegyverszüneti Tárcaközi Bizottság iratai [Documents of the Interdepartmental Committee for Truce].

XIX-F-1-b. Iparügyi Minisztérium, általános iratok [Ministry of Industry, general documents].

XIX-F-1-kk. Bán Antal miniszter iratai [Documents of Minister Antal Bán]

Z 1183 Villamosipari és Kereskedelmi Rt., Ügyvezető igazgatóság [Joint-Stock Company for Electrical Industry and Trade, Managing Directorship]. 


\section{Judit Klement}

Z 1190 Villamosipari és Kereskedelmi Rt., Személyzeti és munkaügyi osztály [Joint-Stock Company for Electrical Industry and Trade, Department of Staff and Labour].

Compass Leonhardt. Vienna, 1929.

Népszabadság, 24 October 1958, 2-3.

\section{Bibliography}

Boyer, Christoph. 'Economic Efficiency and Nationality: The Siemens Subsidiary Elektrotechna in the First Czechoslovakian Republic', in Business and Politics in Europe, 1900-1970: Essays in Honour of Alice Teichova. Edited by Terry Gourvish, 307-324. Cambridge: Cambridge University Press, 2003.

Budapest közúti vasúti közlekedésének fejlödése 1865-1922 és a BSZKRT tízévi múködése, 1923-1933 [The Development of City Rail System in Budapest 1865-1922 and Ten Years of BSZKRT, 1923-1933] Budapest: BSZKRT Directorate, 1934.

Feldenkirchen, Wilfried. Siemens. 1918-1945. Munich and Zurich: Piper, 1995. Feldenkirchen, Wilfried. Siemens. From Workshop to Global Player. Munich and Zurich: Piper, 2000.

Feldenkirchen, Wilfried. Werner von Siemens: Inventor and International Entrepreneur. Columbus: Ohio State University Press, 1994.

Frisnyák, Zsuzsanna and Judit Klement. A Siemens története Magyarországon, 1887-2017 [The History of Siemens in Hungary 1887-2017]. Edited by Orsolya Sebók. Budapest: Siemens Zrt., 2017.

Gábor, Péter. Jóvátétel és külkereskedelmi orientációváltás Magyarországon, 1945 1949/51 [Reparations and Orientation Change in Foreign Trade in Hungary, 1945-1949/51] PhD diss., Pécs: University of Pécs, 2013. Accessed 28 December 2017, http://pea.lib.pte.hu/handle/pea/16125.

Gyarmati, György, Levente Püski, and Róbert Barta. Magyarország a XX. században. I-V. [Hungary in the Twentieth Century] Vol I. Politika, társadalom, hadtörténet, jogalkotás [Politics, Society, Military History, Legislation]. Szekszárd: Babits, 1996.

Honvári, János. A XX. századi magyar gazdaságtörténet [The Economic History of Hungary in the Twentieth Century]. Budapest: Aula, 2006.

Kováts, Lajos. 'A Magyar Repülőgépszerelvénygyár Rt. története 1941-1950' [The History of the Hungarian Aircraft Assembly Plant JSC, 1941-1950], in Tanulmányok Budapest múltjából 26 [Essays on the Past of Budapest, vol. 26.], 153-183. Budapest: BTM, 1997.

Pető, Iván and Sándor Szakács. A hazai gazdaság négy évtizedének története, 1945-1985 [The History of Four Decades of Hungarian Economy, 19451985]. Vol 1. Az újjáépítés és a tervutasításos irányítás időszaka, 1945-1968 [The Period of Reconstruction and the Planned Economy, 1945-1968]. Budapest: Közgazdasági és Jogi Kiadó, 1985.

Pogány, Ágnes. 'Munkabérek a két világháború közötti Magyarországon’ [Wages in the Interwar Period in Hungary], Történelmi Szemle [Historical Review] 31, no. 1-2 (1989): 70-95.

Romsics, Ignác. Magyarország története a XX. században [The History of Hungary in the Twentieth Century]. Budapest: Osiris, 1999.
The Afterlife of a Multinational Enterprise 195

Stark, Tamás. 'War Casualties', in Hungarian Economy and Society During World War II. Edited by György Lengyel, 171-260. New York: Atlantic Research Pubication, 1993.

Tamási, Miklós and Krisztián Ungváry. Budapest, 1945. Budapest: Corvina, 2006.

Vass G., István. 'Dokumentumok a magyar-szovjet jóvátételi egyezmény létrejöttéhez' [Documents Related to the Formation of the Hungarian-Soviet Reparation Agreement], archivNET 11, no. 2 (2011). Accessed 28 December 2017, www.archivnet.hu/diplomacia/dokumentumok_a_magyarszovjet_jovateteli_ egyezmeny_letrejottehez.html.

A Villamosgép és Kábelgyár 50 éve és szerepe a magyar villamosipar fejlödésében, 1913-1963 [50 Years of the Electric Machine and Cable Factory and the Development of the Hungarian Electrical Industry]. Edited by Ferenc Keller. Budapest: KJK, 1963.

Wiesen, S. Jonathan. West German Industry and the Challenge of the Nazi Past, 1945-1955. Chapel Hill and London: University of North Carolina Press, 2001. 
Routledge International Studies in Business History

Series editors: Jeffrey Fear and Christina Lubinski

World Market Transformation

Inside the German Fur Capital Leipzig 1870-1939

Robrecht Declercq

Industries and Global Competition

A History of Business Beyond Borders

Bram Bouwens, Pierre-Yves Donzé, and Takafumi Kurosawa

Commodity Trading, Globalization and the Colonial Word

Spinning the Web of the Global Market

Christof Dejung

Family Dynasties

The Evolution of Global Business in Scandinavia

Hans Siögren

Multinational Business and Transnational Regions

A transnational business history of energy transition in the Rhine region,

1945-1973

Marten Boon

Making Managers in Canada, 1945-1995

Companies, Community Colleges, and Universities

Jason Russell

The Evolution of Business

Interpretative Theory, History and Firm growth

Ellen Mølgaard Korsager

Multinational Enterprise, Political Risk and Organisational Change From Total War to Cold War

Edited by Neil Forbes, Takafumi Kurosawa and Ben Wubs

For a full list of titles in this series, please visit www.routledge.com

\section{Multinational Enterprise, Political Risk and Organisational Change}

From Total War to Cold War

Edited by Neil Forbes, Takafumi Kurosawa and Ben Wubs
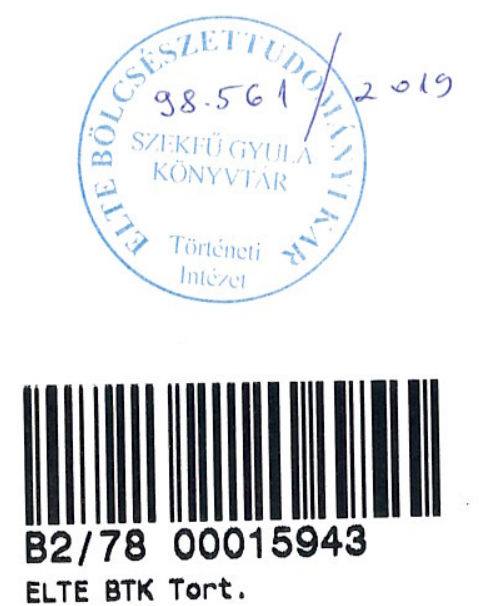

Routledge

Taylor \& Francis Group NEW YORK AND LONDON 
First published 2019

by Routledge

52 Vanderbilt Avenue, New York, NY 10017

and by Routledge

2 Park Square, Milton Park, Abingdon, Oxon, OX14 4RN

Routledge is an imprint of the Taylor \& Francis Group, an informa busines

(C) 2019 Taylor \& Francis

The right of Neil Forbes, Takafumi Kurosawa and Ben Wubs to be

identified as the authors of the editorial material, and of the authors for

their individual chapters, has been asserted in accordance with sections 77 and 78 of the Copyright, Designs and Patents Act 1988.

All rights reserved. No part of this book may be reprinted or reproduced or utilised in any form or by any electronic, mechanical, or other means, now known or hereafter invented, including photocopying and recordins, or in any information storage or retrieval system, without per.

writing from the publishers.

Trademark notice: Product or corporate names may be trademarks or

registered trademarks, and are used only for identification and explanation without intent to infringe.

Library of Congress Cataloging-in-Publication Data

A catalog record for this book has been requested

ISBN: $9781138047822(\mathrm{hbk}$

Typeset in Sabon

by Apex CoVantage, LLC

The editors would like to dedicate this work to Chris Kobrak, dear friend and esteemed colleague, who was drafting his contribution to the volume before his untimely death. 


\section{Contents}

Acknowledgements

List of Contributors

Introduction

NEIL FORBES, TAKAFUMI KUROSAWA AND BEN WUBS

PART I

Geopolitical Risks and Organisational Challenges

1 Swiss and (Anglo)-Dutch Multinationals and Organisational Change in the Era of Total War

TAKAFUMI KUROSAWA AND BEN WUBS

2 Municipalisation, War, Tax and Nationalisation: Imperial Continental Gas Association in an Era of Turmoil, 1824-1987

RYO IZAWA

3 Go West: C\&A's Motives and Strategies for Expansion From Europe Into the Western Hemisphere, 1945-1962 MARK SPOERER

4 Foreign Oil Majors in Japan and the Second World War TAKEO KIKKAWA

PART II

Total War and Long-Lasting Impact

5 Mutual Attraction: Siemens Activities in Italy 1855-1968 LUCIANO SEGRETO 
viii Contents

6 Reinventing the Rio Tinto Company: Spain, Political Risk and Corporate Strategy Before and After the Second World War NEIL FORBES

7 War and Industry Dynamics: The Case of the Industrial Gases Industry After 1940

RAY STOKES AND RALF BANKEN

PART III

Cold War and Corporate Strategies

8 The Afterlife of a Multinational Enterprise: The Case of Siemens' Subsidiary in Hungary After the Second World War JUDIT KLEMENT

9 International Business and the Cold War: The Case of the Trans-European Pipeline, 1956-1960

MARTEN BOON

10 From Cold War to the Washington Consensus: Evolution of the Multinational Corporations' Strategies in Chile MARCELO BUCHELI

Index

\section{Acknowledgements}

We gratefully acknowledge the support provided by the Japanese Society for the Promotion of Science for sponsoring, in 2012, a short-term stay in Japan by means of the JSPS Invitation Fellowship for Research, and also for awarding Grants-in-Aid for Scientific Research (KAKEN), (Project code 15KK0087, 16K13377 and 17H02550). This assistance enabled the ideas that frame this volume to be first adumbrated and then developed, not least during the World Economic History Congress, 2015, held in Kyoto, which provided an excellent forum for discussion; we would like to extend our thanks to all those who participated in our panel session-several of the contributors to the panel are represented in this volume-and to the local organising committee for hosting such a successful Congress. We would also like to acknowledge the opportunity which the European Business History Association Annual Congress, held in Bergen in 2016, afforded us to present a conceptual framework for this study. The supportive and insightful comments we gratefully received from colleagues at that point encouraged us to invite authorial contributions from further, leading scholars. Finally, we would like to express our thanks to Coventry University, Kyoto University and Erasmus University, Rotterdam, for extending the resources, of one kind or another, that have facilitated the work involved in preparing and editing this study. 